DOI: 10.2478/linpo-2013-0005

\title{
THE EVOLUTION OF THE $B$-FUTURE MARKER IN SYRIAN ARABIC
}

\author{
NAJIB ISMAIL JARAD
}

\begin{abstract}
Najib Ismail Jarad. The Evolution of the b-Future Marker in Syrian Arabic. Lingua Posnaniensis, vol. LV (1)/2013. The Poznan Society for the Advancement of the Arts and Sciences. PL ISSN 0079-4740, ISBN 978-83-7654-273-7, pp. 69-85.

The formation of future markers from distinct lexical sources or from similar sources under specific circumstances follows universal pathways. It is standardly agreed that grammaticalization is a process which encompasses a range of changes which involve desemanticization (loss of meaning), decategorialization (loss of categorical features), generalization (use extended to new contexts), and phonetic reduction. The paper assumes that the $b$-prefix derives from two distinct lexical sources: volitional (encoding future) and prepositional (encoding indicative mood, progressive, and habitual aspect), and that the morphological overlap of these two prefixes is a mere coincidence. The paper will concentrate on the development of the future marker ( $b$-prefix) from a verbal noun of volition in Syrian Arabic. The main goal is to explicate the nature of the grammaticalization paths of the $b$-future in Syrian Arabic based on synchronic data. The paper posits that the verbal noun of volition has undergone semantic, structural, and phonological changes.
\end{abstract}

Najib Ismail Jarad, Department of English Language \& Literature, University of Sharjah, UAE, njarad@sharjah.ac.ae

\section{INTRODUCTION}

A large body of research has been done on the evolution of grammatical categories in the languages of the world (e.g., Heine et al. 1991; Hopper \& Traugott 2003; Bybee et al. 1994). According to these scholars, the creation of future markers from distinct lexical sources, or from similar sources at different periods, follows universal pathways. They have identified several grammaticalization pathways through which markers of future time develop cross-linguistically with remarkable regularity. These include motion verbs such 'go' and 'come', volition verbs such as 'want', the verb of action 'do', and the verb to 'have' (HeINE et al. 1991; BYBEE et al. 1994). The grammaticalization pathways of future markers can be represented as follows (Fig. 1).

According to BYBEE et al (1994: 243), among the common pathways to the grammaticalization of the future markers are verbs of desire/volition, obligation, and motion. AITCHISON (2004: 114) argues that 'Verbs of volition, [...], typically become future markers.' Volition is linked to the future through a chain of inferences. Therefore, when I say I want 


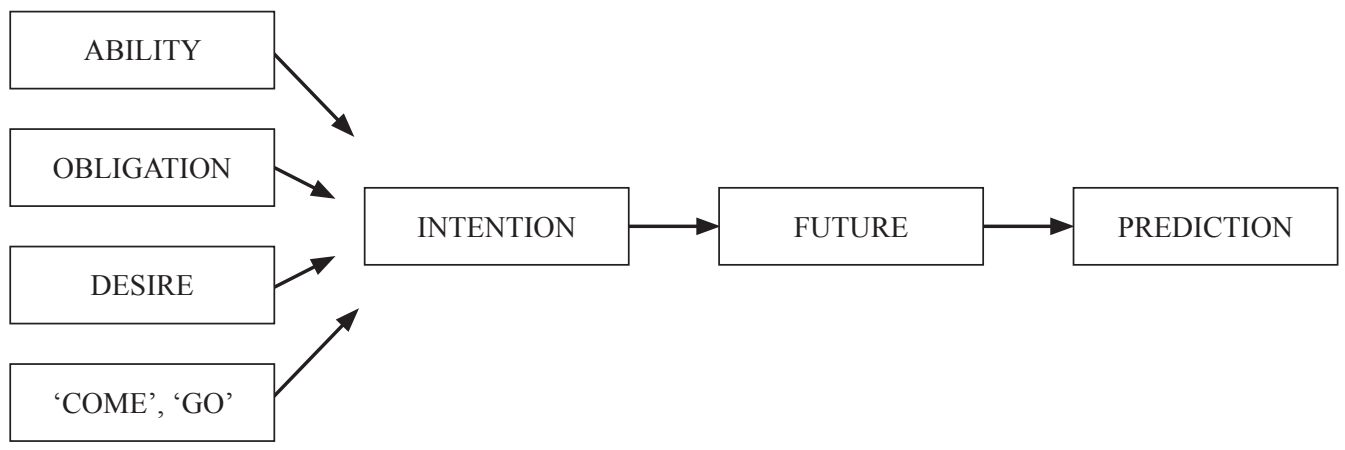

Fig. 1. Pathways of future markers (adapted from ByBEE et al. 1994: 240, 53ff)

to go now, in most contexts, it is reasonable to infer that I in fact intend to go soon and I am communicating this. The transition from lexical to grammatical (modal) status is achieved by "a dramatic frequency increase" (BYBEE et al. 1994: 8; ByBEe 2003: 602) in the number and types of contexts in which the grammatical morpheme is appropriate. Bybee et al. (1994: 256) characterize this pathway as follows:

\section{DESIRE $>$ WILLINGNESS $>$ INTENTION $>$ PREDICTION}

Based on the conventionalizing of the inference 'I want to go' > 'I intend to go soon' > 'I will go (future)', we can assume that the volitional meaning is bleached out leaving only the temporal relation of futurity. ${ }^{1}$

HopPer \& TRAUgOTT (2003: 101) noted that the semantic generality of a lexical item is important for its grammaticalization. This is connected with the fact that a semantically highly specific lexical item has very limited distribution, and it is this limited distribution that does not allow it to become grammaticalized. When the semantic content of a lexical item is lost, the lexical item becomes less restricted in occurrence, i.e. it becomes functionally enriched. Scholars of grammaticalization have argued that the meaning of a lexical item becomes generalized when a metaphor is involved.

According to TraugotT \& DASHer (2002: 27), semantic change is triggered by two mechanisms, namely metaphor and metonymy. Construed as an analogical principle, metaphorization is employed by a language user to express a concept in an abstract domain by means of a concept in a concrete domain.

The second mechanism which triggers semantic change is metonymization. This mechanism is driven by part-whole relation, cause-effect, ellipsis, and "marked implicature" "by which invited inferences in the associate, continuous stream of speech/writing come to be semanticized over time", among which "invited inferences" are given particular attention (TRAUGOTT \& DASHER 2002: 28-29). Invited inferences are cancellable meanings which the speaker invites the hearer to infer. Metaphoric and metonymic processes give rise to invited inferences; that is, speakers invite inferences which are either similar in meaning to or in some way associated with the non-cancellable meanings of the utterances which carry the

1 The development of future markers from a verb of volition is very common cross-linguistically: cf. English will, Greek tha < thelo na 'I wish that' (RoBerTs \& Roussou 2003: 58-71), Danish ville, Bulgarian ste $<$ 'I want that.' (Bybee \& Pagliuca 1987: 112-114). 
inferences. The process which triggers semantic meaning to change can be represented as follows:

\section{INVITED INFERENCE > GENERALIZED INVITED INFERENCE > ENCODED MEANING (i.e. non-cancellable meaning)}

For example, the modal verb 'will' (Old English willan/wyllan) in English used to mean 'to wish, to desire, to want'. The frequently used 'willan' lost its meaning of desire/ wish and assumed the meaning of 'willingness', and from there, 'intention.' The future meaning was then pragmatically inferenced from this intention meaning, and so 'will' generalized from the meaning of 'desire' to the English future tense marker (BYBEE et al. 1994: 254-256).

Whereas there exists a rich body of literature on the evolution of future markers from volition verbs in Romance and Germanic languages (e.g., Ultan 1978; BybEe \& PAGLIUCA 1987; Bybee et al. 1991; HeIne et al. 1991; ByBeE et al. 1994), investigations into the development of future markers in Syrian Arabic are lacking. In light of the above literature, this paper attempts to investigate the lexical source of the $b$-future morpheme in Syrian Arabic.

In Syrian Arabic, speakers insert a $b$-prefix before the imperfect form of the verb to talk about the future, indicative mood, and habitual aspect. Syrian Arabic speakers also indicate future time reference by using another marker which is derived from the motion

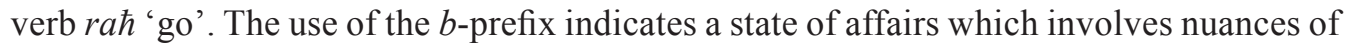
volition, willingness, and intention whereas rah reflects the speaker's certainty that some event is impending in the future and asserts the proximity or imminence of the future event (Hopper \& Traugott 2003: 89; Cowell 2005: 322-323; Mitchell \& El-Hassan 1994: 19). The main aim of this paper is to determine how the verbal noun bi-wuddi (I want/desire) changed into the verb badd (1a, b) and a $b$-prefix marking the future in Syrian Arabic (1c, d).

$$
\begin{aligned}
& \text { badd-i rūh @a-l-bāyt la?anu taß̧ān } \\
& \text { want-I go to-the-house because I-tired } \\
& \text { 'I want to go home because I am tired' } \\
& \text { badd-ak trūh Ya-s-sīnama? } \\
& \text { want-you go to-the-cinema } \\
& \text { 'Do you want to go to the cinema? }
\end{aligned}
$$

maryam w- hasan bysāfro ৎa-bayrūt bukra

Maryam and Hasan $b$-travel to- Beirut tomorrow

'Maryam and Hassan will travel to Beirut tomorrow'

$$
\begin{aligned}
& \text { inšāllah btinjah ha-s-sine? } \\
& \text { by-God's will } \quad b \text {-succeed } \\
& \text { 'I hope you will succeed this year' }
\end{aligned}
$$

Although there are no historical records of Syrian Arabic, the paper will, on the basis of synchronic facts from present-day Syrian Arabic, attempt to provide a reconstruction of the step-by-step evolution of the future marker ' $b-$ '. 
The definition of grammaticalization that is usually espoused in the literature is given by HopPER \& TRAugotT (2003). They define grammaticalization as

"the process whereby lexical items and constructions come in certain linguistic contexts to serve grammatical functions, and, once grammaticalized, continue to develop new grammatical functions."

In other words, grammaticalization is the process whereby lexical categories develop, in specific morphosyntactic contexts, into functional categories, including tense and aspect markers. ${ }^{2}$ Grammaticalization is mainly perceived as a language-internal development and thought of as a slow, diachronic, progressive, unidirectional and irreversible process ${ }^{3}$ (Haspelmath 1999; Hopper \& Traugott 2003: 99-139). Synchronic variations are often regarded as reflecting diachronic development (LEHMANN 1995).

We subscribe to the view that "grammaticalization has to be conceived of as a panchronic process that presents both a diachronic perspective... and a synchronic perspective..." (HEINE et al. 1991: 261). Synchronically, grammaticalization accounts for the existence of multiple usages of a single form at a given point in time and their relative degrees of grammaticalization, hence assuming dynamism in language motivated by semantics and pragmatics. This means that the synchronic structure of a linguistic unit can only be understood in terms of its historical development and is deeply rooted in its paths of grammaticalization over historical time.

Diachronically, grammaticalization sheds light on the evolutionary tracks of a given form. Cross-linguistically, the transition from lexical to grammatical status or from grammatical to even more grammatical status follows a predictable conceptual track called pathway, cline, channel, and chain. The semantic, morphosyntactic, and phonological changes that each lexical item undergoes on its path toward grammaticalization are said to be unidirectional: content word $>$ grammatical word $>$ clitic $>$ inflectional affix (HOPPER \& TRAUGOTT 2003: 7).

This paper investigates the development of the Modern Standard Arabic verbal noun $b i$-wudd-i 'I want/desire' into a grammatical morpheme used to mark the future tense in Syrian Arabic. In spite of the fact that $b i-w u d d-i$ is nominal in origin and in morphology, it functions as a verb ( $b a d d)$ or a marker of futurity. As a marker, it is used to indicate intentionality and future tense. As this lexical verbal noun $b i-w u d d-i$ becomes grammaticalized, it is reduced to a prefix $(b-)$ attached to the imperfect verb when it marks the future tense.

The rest of the paper is organized as follows. First, we look at the development of the Standard Arabic verbal noun $b i$-wudd-i, paying special attention to its use as a full verb. Next, we compare future marking in Standard Arabic and Syrian Arabic. We then look at the grammaticalization of the future marker $(b-)$ in Syrian Arabic. Section 5 provides evidence from other Arabic dialects. Finally, we offer our conclusions.

2 The French linguist Antoine Meillet was the first to recognize grammaticalization as fundamental to diachronic language change in his 1912 article L'évolution des Formes Grammaticales. He calls it "the attribution of grammatical character to an erstwhile autonomous word" (cited in CAMPBELL 1998: 38).

3 For counter examples, see Campbell 2001, Traugott 2001 and Van Der Auwera 2002. 


\section{2. 'BADD’ AS A LEXICAL VERB}

The Standard Arabic verbal noun $b i-w u d d-i$ is used as a lexical verb 'badd' in Syrian Arabic (and other Levantine dialects), typically in the present tense. The verbal nature of 'badd' is supported by the fact that it takes an object NP (1) and embeds a full (2) or bare VP as its complement (3): ${ }^{4}$

$$
\begin{aligned}
& \text { badd-o [NP tuffaha] } \\
& \text { want-he apple } \\
& \text { 'He wants an apple' } \\
& \text { badd-o [vp yākul tuffaha] } \\
& \text { want-he eat apple } \\
& \text { 'He wants to eat an apple' }
\end{aligned}
$$

$$
\begin{array}{ll}
\text { badd-o [ [vP } & \text { yākul] } \\
\text { want-he } & \text { eat }
\end{array}
$$

'He wants to eat'

$$
\begin{array}{ll}
\text { badd-o [ [V } & \text { yenām] } \\
\text { want-he } & \text { sleep }
\end{array}
$$

'He wants to sleep'

A further piece of evidence supporting the verbal nature of ' $b a d d$ ' comes from negation. The negative particle $m \bar{a}$ is used in Syrian Arabic to express sentential negation:

$$
\begin{aligned}
& \text { mā badd-i sayyara Satī?a } \\
& \text { NEG want-I car old } \\
& \text { 'I don't want an old car' } \\
& \text { mā badd-on yenām-o bakīr } \\
& \text { NEG want-they sleep-they early } \\
& \text { 'They don't want to sleep early' }
\end{aligned}
$$

This is the unmarked word order VSO. The negative particle $m \bar{a}$ negates the entire sentence. On the other hand, nominal (verbless) sentences are negated by the particle $m u$, which precedes the non-verbal predicate:

$$
\begin{aligned}
& \text { ahmed mu mabşūţ } \\
& \text { Ahmed not happy } \\
& \text { 'Ahmed is not happy' }
\end{aligned}
$$

4 Note that the verb 'badd' is consistently used with suffixed pronouns. Consider the following set of forms:

\begin{tabular}{|l|l|l|l|}
\hline badd-i & I want & badd-na & We want \\
\hline badd-ak & You (m) want & \multirow{2}{*}{ badd-kon } & You want \\
\hline badd-ik & You (f) want & & \\
\cline { 1 - 2 } badd-u & He wants & \multirow{2}{*}{ badd-on/hon } & They want \\
\hline badd-a/ha & She wants & & \\
\hline
\end{tabular}


(5b)
b. ahmed mu muhandis
Ahmed not engineer

'Ahmed is not an engineer'

Syrian Arabic has two forms of negation: sentential negation marked by the particle $m \bar{a}$ and constituent negation marked by the particle $m u$. Before we proceed to look at the use and development of the $b$-prefix, it is worthwhile to briefly consider how the future tense is expressed in Modern Standard Arabic. The rationale for doing this is to highlight the fact that Syrian Arabic and indeed all other spoken varieties of Arabic have developed their own tense and aspect markers out of lexical sources.

\section{THE FUTURE TENSE IN MODERN STANDARD ARABIC AND SYRIAN ARABIC}

In Modern Standard Arabic, the future tense (al-mustaqbal) is formed by prefixing either the morpheme $s a$ or the particle sawfa to a present tense indicative verb. ${ }^{5}$ The verb may be active or passive. (cf. CoWAN 1964: 88; HASAN 1993: 60; Holes 1995; RYding 2005 : 442). These future markers are used before the imperfect indicative form of the verb to express immediate and remote futurity. The rationale for discussing the future in Modern Standard Arabic (a conservative form of Arabic) is to show that Syrian Arabic has developed completely different particles to mark the future.

The prefix $s a$ - is attached to the verb to express the immediate future. Consider the following examples:

$$
\begin{aligned}
& \text { sa-yaštari ahmed sayyārat-an } \\
& \text { FUT-buy Ahmed car-ACC } \\
& \text { 'Ahmed will buy a car' } \\
& \text { sa-yuyādiru ahmed ila 1-maţāri fil hāli } \\
& \text { FUT-leave Ahmed to the-airport soon } \\
& \text { 'Ahmed will leave for the airport soon' } \\
& \text { sa-yarkabu aţ- ţāir-a hālan } \\
& \text { FUT-ride the-plane-ACC soon } \\
& \text { 'He will board the plane soon' }
\end{aligned}
$$

In the above examples, the future prefix $s a$-expresses the fact that the intended activity is likely to happen in the near future. Crucially, the time adverbial 'fil hāli' or 'hālan' 'soon'

5 It should be pointed out that the two future markers ( $s a w f a, s a$-) can also be followed by the passive form of the verb. Similarly, both $s a$ - and sawfa indicate immediate and remote futurity. Other tenses like the simple present and the present continuous may also be used to express futurity depending on context. For example:

(i)

$$
\begin{aligned}
& \text { tuţāidu š-šurţah al-luşa alpān } \\
& \text { chase the-police the-thief now } \\
& \text { 'The police are chasing the thief now' }
\end{aligned}
$$

(ii) yusāfiru aћmad Pila landun nihāyata al-PusbūYi

leave Ahmed to London end the- week

'Ahmad will travel to London at the weekend' 
are optional since they only emphasize the fact that the intended activity is going to happen in a short time.

The second future marker sawfa is used before the verb to express the remote future. Consider the examples below. ${ }^{6}$

$$
\begin{array}{lll}
\text { sawfa yaštari ahmed sayyārat-an } & \text { yadan } \\
\text { FUT buy Ahmed car-ACC } & \text { tomoroow } \\
\text { 'Ahmed will buy a car tomorrow' } &
\end{array}
$$

sawfa yaštari aћmed sayyārat-an al-Pisbūৎ al-qādimi

FUT buy Ahmed car-ACC the-week the-next

'Ahmed will buy a car next week'

sawfa yuyādiru ahmed Pila l-maţāri baৎda sā̧at-ayn

FUT leave Ahmed to the-airport after hours-two

'Ahmed will leave for the airport after two hours'

sawfa yadrusu ahmad al-Padab-a il-injlīziyy-a al-\{ām alqādim

FUT study Ahmed the-literature-ACC the-English the-year-the-next

'Ahmad will study English literature next year'

As evident from the examples in (2), the future marker sawfa is associated with a time adverbial whenever the remote future is used, for instance, in (2a) the activity is not going to take place at the immediate future. However, the presence of the time adverbial ' $\mathrm{y}$ adan' with sawfa is not obligatory as the particle itself indicates remoteness.

Syrian Arabic shows considerable variation with regard to the expression of future. Syrian Arabic generally expresses futurity by using the verb 'badd' (want) or by prefixing the particle $b$ - to the imperfect verb form (Cowell 2005: 347). ${ }^{7}$ Mitchell \& EL-Hassan (1994: 13) argue that the '[...] $b$-nonpast (i.e. imperfect verb form) is often of straightforward future reference'. Let's first look at examples with 'badd' and $b$ - in main clauses:

$$
\begin{aligned}
& \text { badd-i Pirjaৎ } \text { Sa-l-bāyt } \\
& \text { want-I return to-the-house } \\
& \text { 'I want to go back home' }
\end{aligned}
$$

$$
\begin{array}{llll}
\text { jār-na } & \text { badd-o } & \text { yezūr-na } & \text { bukra? } \\
\text { neighbor-our } & \text { want-he } & \text { visit-us } & \text { tomorrow }
\end{array}
$$

'Our neighbor wants to visit us tomorrow'

6 The use of the morpheme $s a$ or the particle sawfa before the imperfect indicative form of the verb has been investigated by several researchers. BADAWI et al. (2004: 366) and AL-KHAWALDA (2000: 75) noted that the choice between them is free whereas Hasan (1993: 60), AlkhUli (1997: 46) and Khalil (1999: 193) assume that sawfa expresses remote future. I am grateful to an anonymous reviewer for highlighting this point.

7 As we mentioned earlier, Syrian Arabic has another future marker which comes from the lexical verb $r \bar{a} \hbar$ with the movement meaning of 'go'. Cowell (2005: 322) calls rā̄ (translatable as 'going to') 'the particle of anticipation', which generally expresses a future for which there is an intention or there is evidence of what going to happen. The discussion of the use of the verb $r \bar{a} \hbar$ as a future marker in Syrian Arabic falls beyond the scope of the present study and, therefore, will not be attempted. 
(3c) badd-ak yaha mowazafi wala sitbāyt?

Want-you her employee or housewife

'Do you want her to be an employee or a housewife?'

(4a)

$\begin{array}{lll}\text { maryam w-hasan } & \text { bysāfr-o } & \text { 〔a-š-šām bukra } \\ \text { Maryam and Hassan } & b \text {-travel-they } & \text { to- the-sham }\end{array}$

'Maryam and Hassan will travel to Damascus tomorrow'

(4b) b. mā byezৎal minn-ak

NEG $\quad b$-he-upset from-you

'He won't be mad with you'

$\begin{array}{lllll}\text { inšalla mā byersob fì-Pimtihān } & \text { s-swāia } & \text { bukra } \\ \text { if God will NEG } & b \text {-he-fail } & \text { in-test } & \text { the-driving } & \text { tomorrow } \\ \text { 'Hopefully, he won't fail the driving test tomorrow' } & \end{array}$

A to B: btəjawwazī-ni B to A: ţabৎan btəjawwaz-ak $b$-you-marry-me of course, $b$-I-marry-you

'Will you marry me? Of course, I will marry you'

$$
\begin{aligned}
& \text { bkūn Yand-ak s-sāৎa sabৎa } \\
& b \text {-be with-you the-hour seven } \\
& \text { 'I will be with you at seven' }
\end{aligned}
$$

The following examples show the use of ' $b a d d$ ' and ' $b$-' in embedded clauses:

$\begin{array}{llll}\text { bezin Pinno ahmed badd-o } & \text { yudros } & \text { ţ-ţob } \\ \text { think that } & \text { Ahmed want-he } & \text { study } & \text { the medicine }\end{array}$

'I think that Ahmed wants to study Medicine'

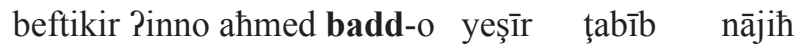

believe that Ahmed want-he become physician good

'I believe that Ahmed wants to become a good physician'

waSad-ni Pinno byedros afd'al ha-seni

promised-me that-he $b$-study better this year

'He promised me that he would study better this year'

beẓin Pinno ahmed byenjah fi-s-sānawei ha-s-seni

think-I that Ahmed $b$-succeed in the secondary this year

'I think Ahmed will pass the GCSE this year'

The above examples show that $b$-prefix seems to indicate nuances of volition, willingness, intentionality and future. The $b$-prefix can also be used in polite questions (6) and conditional sentences (7) to express modal future:

btišrab Pahwi?

$b$-you-drink coffee?

'Would you like to drink coffee?' 
(6b)

(7a)

$\begin{array}{lll}\text { bithibb } & \text { tišrab } & \text { šey? } \\ b \text {-you-like } & \text { drink } & \text { something }\end{array}$

'Would you like to drink anything?'

Piza btedros kwayes, bištrī-lak lab tob

if $\quad b$-you-study well $\quad b$-buy-you lap top

'If you study well, I'll buy you a laptop'

(7b)
law kān mại maşāri ziyyādih, kint biৎţī-k šwayy
if was with-me money extra, was-I $b$-give-you some
'If I had extra money, I'd give you some'

It should be pointed out here that the $b$-prefix is widely used in both main and embedded clauses to form the indicative mood, progressive or habitual aspect (COWELL 2005: 356; Mitchell \& El-Hassan 1994: 13, 19-24). Brustad (2000: 251) argues that when (b-) occurs in a verb phrase headed by temporal verbs, it adds a stative dimension to the verb phrase.

$$
\begin{aligned}
& \text { bid'all btehki w- bteћki } \\
& b \text {-she-continue } \quad b \text {-talks and } b \text {-talks } \\
& \text { 'She keeps on talking and talking' } \\
& \text { byerūh Sal-jim kill yom } \\
& b \text {-he-go to the gym every day } \\
& \text { 'He goes to the gym every day' } \\
& \text { Payy sāৎa bitrūh Sa-1-maktab } \\
& \text { what hour } \quad b \text {-you-go to-the-office } \\
& \text { 'What time do go to the office?' }
\end{aligned}
$$

Payy sāৎa bterją $\quad$ Sa-l-bāyt
what hour $\quad b$-you-return to-the-house
'What time do you come home'

$\begin{array}{llll}\text { kam marra } & \text { btel؟ab } & \text { ryād'a } & \text { bi-1-Pisbū } \\ \text { how times } & b \text {-you-play } & \text { sport } & \text { in-the-week }\end{array}$

'How many times do you play sport a week?'

Crucially, the indicative ( $b-)(8 a)$ focuses attention on the stativity of the act of speaking and on the habituality of the activity in (8b-e).

The prefix $(b-)$ is also used to talk about generalized statements: statements with some sort of permanent truth value:

$$
\begin{aligned}
& \text { b-taSrif inglīzi mnīh } \\
& b \text {-you-know English well } \\
& \text { 'You know English well' } \\
& \text { b-tiSjib-ni ktīr } \\
& \text { b-like-I much } \\
& \text { 'I like it a lot' }
\end{aligned}
$$


Based on the above data, we can conclude that the $b$-prefix in Syrian Arabic can be used to talk about future, habituality, and generalized statements. Note that future, habitual, and generic statements all involve a future time reference.

The question arises as to whether the $b$-prefix derives from the verbal noun $b i$-wud- $i$ ( $b i-w u d-i>b a d d>b$-) or from the preposition $b i$ - 'in, by, with'. ${ }^{8}$ We assume that Syrian Arabic has two separate $b$-prefixes, each with its own origin. That is, the $b$-prefix that marks the future derives from the verbal noun $b i$-wud-i (via $b a d d$ ) whereas the $b$-prefix that marks the indicative mood, progressive or habitual aspect derives from the preposition $b i$ - 'in, by, with' (BRUSTAD 2000: 253). The assumption that the $b$-prefix that marks the future derives from the verbal noun $b i$-wud- $i$ ( $b i$-wud-i $>$ badd $>b$-) is supported by the fact that the vo-

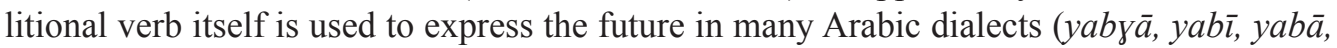
yibbi, $b a, b$ - 'want, desire' in Gulf Arabic, badd, ba-, bi-, b- 'want' in Levantine, bat, biti, bit, $b a$ - which derive from $b \gamma \bar{a}, b \gamma \bar{a} t$, byit 'want' in Moroccan Arabic, and yāba, yibbi, ba'want' in Libyan (STEWART 1998: 110) (see section 5 for examples).

The assumption that the $b$-prefix that marks the indicative mood, progressive or habitual aspect derives from the preposition $b i$ - 'in, by, with' is supported by the fact that this $b$-prefix is obligatory in progressive contexts in Egyptian Arabic. This is further supported by COMRIE's (1976: 103) assumption that progressive constructions are locative in origin. The progressive use is extended to describe habitual and generic situations, i.e. progressives tend to develop into general imperfectives (BYBEE \& DAHL 1989: 56f.; BYBEe et al. 1994: 141). In Egyptian Arabic, MCCARUs (1990: 103) states that when the meaning of the verb is progressive, the indicative mood marker $b i$ - is 'obligatory, optional but usual if the meaning is habitual, and usually deleted if the meaning is stative.' MCCARUs (1990: 104) adds that the spread of the $b$-prefix to stative verbs in Egyptian Arabic 'was relatively recent, and is limited in this usage.'

\section{THE EVOLUTION OF THE FUTURE MARKER $(b-)$}

Cross-linguistically, the future is marked in similar ways in most of the world languages. ByBEE et al. (1994: 159) argue that markers of futurity in the languages of the world most often develop from "constructions expressing obligation or necessity, desire, and movement or intention." Furthermore, TRASK (1996: 144) claims that verbs meaning 'want', 'go', 'must' and 'come' develop into functional markers of futurity in the languages of the world. Thus, there are three paths of development of future markers: the movement path, the volition path, and the obligation path. In this paper, focus is placed on the volition path. (cf. Bybee \& Pagliuca 1985: 67; Joseph 1983: 1; Heine \& ReH 1984: 131 for the development of future markers in English, Balkan Peninsula languages, and Swahili). Given the fact that grammaticalization leads to the rise of an item with a functional meaning, it is reasonable to assume that this new grammaticalized item can be incorporated into the morphological paradigm of a language. For example, the future marker will in English originates as a lexical verb meaning 'desire' (see RoBerts \& Roussou 2003, chapter 5 for a discussion of Greek thelo).

8 I am grateful to an anonymous reviewer for raising this question. 
The first stage in the development of ( $b$-) as a future marker is that the verbal noun $b i$-wudd- $i$ is bleached out of its semantic content. This amounts to saying that $b i$-wudd-i lost its argument structure, i.e. as a lexical verbal noun $b i$-wudd-i had argument structure, and when it became a functional element, it lost its argument structure. For example, in Standard Arabic, as a verbal noun $b i$-wudd-i is a predicate which subcategorizes for anNP(TOPIC) ${ }^{9}$ and a sentential complement introduced by the complementizer 'Pann' (that) or 'law' (if) in Modern Standard Arabic:

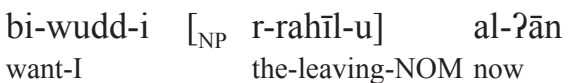

$$
\begin{aligned}
& \text { 'I want to leave/go now' }
\end{aligned}
$$$$
\text { bi-wudd-i [ [CP Pann Pakula tuffāhat-an al-Pān] }
$$$$
\text { want-I that I-eat apple-ACC now }
$$$$
\text { 'I want to eat an apple now' }
$$

$$
\begin{aligned}
& \text { bi-wudd-i [ } \left.\text { [CP }_{\mathrm{C}} \text { law tazūr-na fī nihayati al-PisbūS }\right] \\
& \text { want-I if you-visit-us in end the-week }
\end{aligned}
$$

$\begin{array}{llll}\text { * bi-wudd-i [vp } & \text { Pakula tuffāhat-an al-?ān }] \\ \text { want-I } & \text { eat apple-ACC now }\end{array}$

'I want to eat an apple now'

When $b i-w u d d-i$ is reanalyzed as a future marker $(b-)$, it is not compatible with any argument structure. In the absence of any argument structure, what remains is the purely modal content of the verbal noun $b i-w u d d-i$. In other words, the volitional meaning associated with a theta-role for the external role of $b i-w u d d-i$ is bleached out leaving only the temporal relation of futurity. According to BYBEE et al. (1994), this change is a change from an agentoriented to a speaker-oriented modality. Also, the grammaticalization of $(b-)$ as a future marker involved the metaphorical extension of the original meaning, i.e. a change from the cognitive domain of [+want] to the abstract domain of time ( $(b-)$ as a future particle).

In addition to denoting 'intention, the $b$-prefix clearly expresses the future, especially when the subject is an inanimate NP:

$$
\begin{aligned}
& \text { Pemta bţīr eţ-ţayyāra } \\
& \text { when b-fly the-plane } \\
& \text { 'When will the plane take off? }
\end{aligned}
$$

$$
\begin{aligned}
& \text { l-film byebda Pisā̧a tişa } \\
& \text { the-film b-start hour nine } \\
& \text { 'The movie is to start at nine o'clock' }
\end{aligned}
$$

The use of inanimate subjects in that position argues against any sense of 'intention' in such situations. Therefore, only future or prediction can be attached as a semantic feature.

The second stage in the development of $(b-)$ as a future marker is the fusion of the preposition ' $b i$ ' and the verbal noun ' $w u d d$ ' into a lexicalized verb of volition 'badd/bidd' (cf. EsSEESY

9 In Standard Arabic, verbless sentences consist of a subject or TOPIC (mubtada?) and predicate or COMMENT (xabar). The topic typically begins with a noun phrase or pronoun, and the comment may take the form of different classes of words and phrases: nouns, pronouns, adjectives, or prepositional phrases. 
2007: 194). Since the preposition 'bi' ends with a vowel, the glide 'w' of the verbal noun ' $w u d d$ ' is dropped, further vowel truncation of ' $u$ ' follows in accordance with the general tendency in the Arabic phonotactics to rule out the occurrence of more than two vowels in a row. Thus, both the grammaticalized element and the lexical verb coexist in Syrian Arabic. This is called layering. According to HOPPER (1991: 22) layering is a condition where new functions and meanings have emerged, but the old ones still coexist. BYBEE et al. (1994: 21) confirm that '[...] the rise of new markers is not contingent on the loss or dysfunction of its predecessor'. Layering is followed by divergence, which describes a phenomenon in which a lexeme has grammaticalized into a clitic or affix, but its original form is retained. Divergence is also followed by specialization. As the grammaticalization of ' $b a d d$ ' proceeds, the number of possible choices is gradually narrowed down and the $b$-prefix is specialized for this particular function (i.e. intentionality) and finally becomes obligatory in this respective context.

The third stage in the development of 'badd' into future marker is accompanied by phonological reduction: syllabic erosion reduces the form by shortening $b a d d>b a-$. The resultant form underwent further erosion such that the vowel is dropped (e.g., $b a->b$ ).

$$
\begin{aligned}
& \text { badd-i šūf-ak bukra Gand maw Pif 1-bāş } \\
& \text { want-I see-you tomorrow at stop the-bus } \\
& \text { 'I want to see you tomorrow at the bus stop' }
\end{aligned}
$$

ba-šūf-ak bukra Sand maw?if 1-bāş
$b a$-see-you tomorrow at stop the-bus
'I will see you tomorrow at the bus stop'

bšūf-ak bukra Yand maw?if 1-bāş
$b$-see-you tomorrow at stop the-bus
'I will see you tomorrow at the bus stop'

Crucially, the phonological reduction of ' $b a d d$ ' into $(b-)$ is not sensitive to the syntactic configuration in which it occurs. More specifically, examples like those below show that phonological reduction is allowed when 'badd' is followed by a movement:

$$
\begin{array}{lll}
\text { Pilli wēn } & \text { badd-ak tnām } t_{\mathrm{i}} \text { bukra } \\
\text { tell-me where } & \text { want-you sleep tomorrow }
\end{array}
$$

'Tell me where you will sleep tomorrow'

$$
\begin{aligned}
& \text { Palli wēn }{ }_{\mathrm{i}} \quad \text { b-tnām } t_{\mathrm{i}} \text { bukra } \\
& \text { Tell-me where } \quad b \text {-you sleep tomorrow } \\
& \text { 'Tell me where you will sleep tomorrow' }
\end{aligned}
$$

However, the phonological reduction of 'badd' into ( $b$-) is ruled out when 'badd' is followed by a VP deletion:

$$
\begin{aligned}
& \text { ahmad baddo yəšteri sayyara jdīdeh w- omar baddo [VP__ } \\
& \text { Ahmad want-he buy car new and Omar want-he }
\end{aligned}
$$

$\begin{array}{llll}\text { *ahmad badd-o yəšteri sayyara jdīdeh } & \text { w- omar b- } \\ \text { Ahmad want-he buy car new } & \text { and Omar } b \text { - }\end{array}$

'Ahmad wants to buy a new car and Omar wants to as well' 
The sentence in (12) is disallowed because prefixes cannot be stranded. Interestingly enough, the ungrammaticality of (12) above can be related to the impossibility of auxiliary contraction with VP-ellipsis in English:

$$
\begin{aligned}
& \text { John will buy a car, and I will [ } \mathrm{VP}_{\mathrm{VP}}[\text { ] }] \text { too. } \\
& \text { *John will buy a car, and I'll [ }\left[\mathrm{VP} \_ \text {] }\right] \text { too. }
\end{aligned}
$$

As we have noted earlier the lexical verb 'badd' was subject to phonological reduction. Pragmatic inferencing, as an important mechanism of change, is quite apparent and instrumental in the development of the future forms in Syrian Arabic: the future meaning is inferred by the hearer from constructions in which intention is indicated.

The observation that the grammaticalization of the future marker in Syrian Arabic involves phonological reduction is not new. For example, Hopper \& TraugotT (2003: 7) have discussed the 'cline of grammaticality', ${ }^{10}$ along the lines of:

$$
\text { content item }>\text { grammatical word }>\text { clitic }>\text { inflectional affix }
$$

We concur with RoBeRTs \& Roussou (2003: 225) that phonological change is a natural process in human language but is not reliant on syntactic change. However, grammaticalization results in a more dramatic phonological change affecting the grammaticalized items. We could safely claim that high frequency of the $b$-future marker in Syrian Arabic contributes to its phonological reduction (BYBEE 2007). This high frequency of the $b$-future marker in conversational discourse in Syrian Arabic results from an increase in the number and types of contexts in which the gram (i.e. $b$-prefix) is appropriate.

Therefore, the evolution of the future marker $(b-)$ in Syrian Arabic might be represented as follows:

$$
\text { bi-wudd-i } \rightarrow\left\{\begin{array}{l}
\rightarrow \text { badd (lexical) } \rightarrow \text { badd } \\
\rightarrow \text { badd (grammatical) } \longrightarrow \text { b(i)- }
\end{array}\right.
$$

The structural, phonological, and semantic changes of the $b$-prefix discussed above can also be explained by a process of metaphorization. Fundamentally, the shift involves the change from a concrete object or an animate NP to an abstract idea. A related mechanism that promotes the change of meaning is pragmatic strengthening. When the subject is something unable to exercise volition, a "desire/want" reading is ruled out. The interpretation of the utterance then relies on the situational context in which $b$ - is used.

\section{CROSS-DIALECTAL EVIDENCE}

The development of future markers from distinct lexical sources is also attested in several Arabic dialects. KAYE (1987: 575) observes that "The colloquial Arabic dialects have felt the need for finer distinctions, in addition to the perfectlimperfect, and have developed

${ }^{10}$ According to Hopper \& Traugott (2003: 7), "The term "cline" is a metaphor for the empirical observation that cross-linguistically forms tend to undergo the same kinds of changes or have similar sets of relationships, in similar orders." A cline is thus both diachronic (a schema of evolution) and synchronic (the co-existence of all the forms). 
overt tense markers such as $\hbar a$ - marking future in Egyptian Arabic (from the motion verb $r \bar{a} \hbar$ 'go') and other colloquial dialects." Egyptian Arabic also uses ( $b-$ ) as a marker of factual statements, a progressive marker, and a marker of predictions about the future. Consider the following examples from (HoLEs 2004: 226-227):

$$
\begin{aligned}
& \text { byi?ra } \\
& b \text {-3msg-read } \\
& \text { 'He reads/can read' } \\
& \text { byi?ra ktīr } \\
& b \text {-3msg-read much } \\
& \text { 'He reads a lot' } \\
& \text { byi?ra ktāb } \\
& b \text {-3msg-read book } \\
& \text { 'He's reading a book' } \\
& \text { byi?ra 1-ktāb bukra } \\
& b \text {-3msg-read the-book tomorrow } \\
& \text { 'He'll read the book tomorrow' }
\end{aligned}
$$

Note that the prefix $(b-)$ marks the habituality of the activity in $(1 \mathrm{a}, \mathrm{b})$ while it marks the continuity of the activity in (1c) and makes prediction about the future in (1d). However, it should be highlighted that the most common particle that Egyptian speakers use to signify future reference is ( $\hbar a-)$ derived from the motion verb $r \bar{a} \hbar$ ' $g o$ '.

In Gulf Arabic, the future is also formed by prefixing the particle $(b-)$ on the imperfect form of the verb. According to Holes (1990: 188), the future particle, which is believed to be a shortened form of the Classical/Standard Arabic lexical verb Pabyi 'I want', has a "modal colouring" which conveys speaker intent. Johnstone (1967: 143, 152, 163, 169) considers the $b i$ - prefix to have future meaning with a sense of volition in Kuwaiti, Bahraini and Qatari dialects and is also used to signal future tense in the dialects of Abu Dhabi, Dubai, and the Buraimi oasis on the border between the UAE and Oman. Johnstone also noted that $b(i)$ - usually has the sense of volition whereas $r \bar{a} \hbar$ usually indicates intention.

Al-NAJJAR (1991: 666-667) proposed that the future marker in Kuwaiti Arabic had developed from the lexical verb ?abi 'I want' which in turn had evolved from the Classical Arabic verb ?abyi 'I want'. The following examples illustrate (transcription, mine):

$$
\begin{aligned}
& \text { Pabi arūh il-madriseh } \\
& \text { I-want I-go the-school } \\
& \text { 'I want to go to school' }
\end{aligned}
$$

$$
\begin{aligned}
& \text { sāmi yabi yšūf maryam fi l-hafle } \\
& \text { sami he-want he-see maryam in the party } \\
& \text { 'Sami wants to see Maryam (at the party)' } \\
& \text { ba-rūh il-madriseh } \\
& \text { b-I-go the-school } \\
& \text { 'I will go to school' }
\end{aligned}
$$$$
\text { sami he-want he-see maryam in the party }
$$ 


$$
\begin{aligned}
& \text { sāmi bi-yšūf maryam fi 1-hafle } \\
& \text { sami b-he-see maryam in the-party } \\
& \text { 'Sami will see Maryam at the party' }
\end{aligned}
$$

Al-Najjar notes that in examples (2) and (3) the lexical verb (y)abi expresses desire or intention in the present tense, whereas in (4) and (5) it was reduced to the future marker. However, it should be highlighted here that the lexical verb ?abi is still used as a lexical verb in Kuwaiti Arabic to express the meaning of want or desire (for more examples, see Al-NAJJAR 1991: 667).

Persson (2008) conducted a survey of the use of the $b$-prefix in Gulf Arabic dialects. She argues that not only does the $b$-prefix encode future tense or intentive mood or a combination of both but also a generalized marking of irrealis mood (cf. HoLEs 2000: 34 \& ft 145).

\section{CONCLUSION}

Now that I have given an account of the presumed origin of the future $b$-prefix in Syrian Arabic, I want to provide some concluding remarks. Like many other languages, Syrian Arabic has grammaticalized a verb of volition to a future tense marker. The data investigated in this paper revealed that the Standard Arabic verbal noun $b i-w u d d-i$ developed first into a lexical verb badd 'want' and then into a prefix $(b-)$ marking the future tense both in main and subordinate clauses. This amounts to saying that the verb badd shifted from expressing concrete meanings to expressing more abstract grammatical meanings, i.e. the lexical meaning of the verb was "bleached out." As a lexical verb requiring human subjects, the use of badd was extended to contexts involving inanimate subjects. Being used as a tense marker, badd underwent decategorialization: it lost its status as an independent word and became a prefix of the main verb. Finally, badd underwent phonetic reduction, being reduced to $b$ - in main clauses and subordinate clauses. Although badd underwent semantic, morphosyntactic, and phonetic changes or losses, its uses were extended to new contexts.

The evolution of badd into a future marker was argued to be triggered by two conceptual mechanisms: metaphorization and metonymization. Metaphorization led first to the semantic shift from [+want] to [+intention] accompanied by a categorical shift of a lexical verb to a prefix, and second, to the development of future. Metonymization motivated wider range of uses and meaning change, including the pragmatic strengthening of intentionality.

\section{ACKNOWLEDGMENT}

I am deeply indebted to two anonymous reviewers for their insightful comments and suggestions. I am also grateful to Ian Roberts for his comments and suggestions on an earlier version of this paper. All remaining errors and shortcomings are my sole responsibility.

\section{REFERENCES}

Al-Khawalda Mohammad. 2000. “The Expression of Futurity in the Arabic and English Languages.” In: IBRAHIM et al. 2000: 70-76.

Alkhuli Muhammad Ali. 1997. Comparative Linguistics: English and Arabic. Jordan: Daralfalah. 
Al-NaJjar Balkees. 1991. "Grammaticalization of Lexical Markers in Kuwaiti Arabic." Folia Linguistica 25, 665-674.

Aitchison Jean. 2004. Language Change: Progress or Decay. Third edition. Cambridge: Cambridge University Press.

BADAwi Elsaid, CARTer Michael G., Gully Adrian. 2004. Modern Written Arabic: A Comprehensive Grammar. London-New York: Routledge.

Bellamy James A. (ed.). 1990. Studies in Near Eastern Culture and History in Memory Ernest T. Abdel-Massih. Ann Arbor, Michigan: University of Michigan.

Brustad Kristen E. 2000. The Syntax of Spoken Arabic. Washington, D. C.: Georgetown University Press.

Bybee Joan. 2003. "Mechanisms of Change in Grammaticization: The Role of Frequency." In: JANDA \& JosePH 2003: 602-623.

Bybee Joan, Dahl Östen. 1989. "The Creation of Tense and Aspect Systems in the Languages of the World." Studies in Language 13(1), 51-103.

Bybee Joan, Pagluica William. 1985. "Cross-linguistic Comparison and the Development of Grammatical Meaning.” In: FisIAK 1985: 59-83.

Bybee Joan, Pagliuca William. 1987. "The Evolution of Future Meaning." In: Ramat et al. 1987: 109-122.

Bybee Joan, Pagliuca William, Perkins Revere D. 1991. "Back to the Future.” In: Traugott \& Heine 1991, vol. II: $17-58$.

Bybee Joan, Perkins Revere, Pagliuca William. 1994. The Evolution of Grammar: Tense, Aspect and Modality in the Languages of the World. Chicago: University of Chicago Press.

BybeE Joan. 2007. Frequency of Use and the Organization of Language. New York: Oxford University Press.

CAmpbell Lyle. 1998. Historical Linguistics. Edinburgh: Edinburgh University Press.

CAmpbell Lyle. 2001. "Grammaticalization: A Critical Assessment." (Special issue of Language Sciences 23).

Comrie Bernard. 1976. Aspect. Cambridge: Cambridge University Press.

Comrie Bernard (ed.). 1987. The World's Major Languages. New York: Oxford University Press.

Cowan David. 1964. An Introduction to Modern Literary Arabic. Cambridge: Cambridge University Press.

Cowell Mark W. 2005 [1964]. A Reference Grammar of Syrian Arabic. Washington DC: Georgetown University Press.

EsSEesY Mohsen. 2007. “Grammaticalization.” In: VerSTEEGH et al. 2007, vol. 2: 191-198.

FisIAK Jacek (ed.). 1985. Historical Semantics, Historical Word Formation. The Hague: Mouton.

Greenberg Joseph (ed.). 1978. Universals of Human Language, vol. III. Stanford: Stanford University Press.

HaSAn Abbās. 1993. Al-Naḥw al-wāfì. Vol. 4. Cairo: Dār al-Ma ārif [in Arabic].

HASPELMATH Martin. 1999. "Why is Grammaticalization Irreversible?" Linguistics 37(1), 43-68.

HeINe Bernd, ReH Mechthild. 1984. Grammaticalization and Reanalysis in African Languages. Hamburg: Helmut Buske Verlag.

Heine Bernd, Claudi Ulrike, Hünnemeyer Friederike. 1991. Grammaticalization: A Conceptual Framework. Chicago: The University of Chicago Press.

Holes Clive. 1990. Gulf Arabic. London: Routledge.

Holes Clive. 1995. Modern Arabic. London: Longman.

Holes Clive. 2000. Dialect, Culture and Society in Eastern Arabia. Vol. 1: Glossary (Handbuch der Orientalistik). Leiden-Boston: Brill.

Holes Clive. 2004. Modern Arabic: Structures, Functions, and Varieties. Washington: Georgetown University Press.

Hopper Paul J. 1991. “On Some Principles of Grammaticalization.” In: Traugott \& Heine 1991, vol. I: 17-36.

Hopper Paul J., Traugott Elizabeth Closs. 2003. Grammaticalization. Second edition. Cambridge: Cambridge University Press.

Ibrahim Zaynab M., Aydelott Sabiha T., Kassabgy Nagwa (eds.). 2000. Diversity in Language. Cairo: The American University in Cairo Press.

JANDA Richard D., JosePh Brian D. (eds.). 2003. Handbook of Historical Linguistics. Oxford: Blackwell.

Johnstone Tomas M. 1967. Eastern Arabian Dialect Studies. London: Oxford University Press.

JosepH Brian D. 1983. The Synchrony and Diachrony of the Balkan Infinitive. Cambridge: Cambridge University Press.

KaYe Allan S. 1987. “Arabic.” In: Comrie 1987: 664-685.

Khalil Aziz M. 1999. A Contrastive Grammar of English and Arabic. Jordan: Jordan Book Centre. 
Lehmann Christian. 1995 [1982]. Thoughts on Grammaticalization. Munich: Lincom Europa. (First Published [1982] as akup 48, University of Cologne.).

McCarus Ernest N. 1990. "A Case of Semantic Reconstruction: The Egyptian Arabic Verbal Prefix Bi-." In: Bellamy 1990: 127-139.

MeiLlet Antoine. 1912. "L'évolution des formes grammaticales." Scientia 12, 384-400.

Mitchell Terence Frederick, El-Hassan Shāhir. 1994. Modality, Mood and Aspect in Spoken Arabic with special reference to Egypt and the Levant. Library of Arabic Linguistics, Monograph 11. London-New York: Kegan Paul International.

Persson Maria. 2008. "The Role of the $b$-prefix in Gulf Arabic Dialects as a Marker of Future, Intent and/or Irrealis." Journal of Arabic and Islamic Studies 8, 26-52.

Ramat Anna Giacalone, Carruba Onofrio, Bernini Giuliano (eds.). 1987. Papers from the 7th International Conference on Historical Linguistics. Amsterdam: Benjamins.

RoberTs Ian, Roussou Anna. 2003. Syntactic Change: A Minimalist Approach to Grammaticalization. Cambridge: Cambridge University Press.

Ryding Karin. 2005. A Reference Grammar of Modern Standard Arabic. Cambridge: Cambridge University Press.

Stewart Devin J. 1998. "Clitic Reduction in the Formation of Modal Prefixes in the Post-Classical Arabic Dialects and Classical Arabic Sa-/Sawfa." Arabica 45, 104-128.

Trask Robert Lawrence. 1996. Historical Linguistics. London: Arnold.

TraUgott Elizabeth Closs. 2001. "Legitimate Counterexamples to Unidirectionality." Available at: http://www. stanford.edu/ traugott/ect-papersonline.html (2013.04.04).

Traugott Elizabeth Closs, Heine Bernd (eds.). 1991. Approaches to Grammaticalization. Amsterdam: John Benjamins.

Traugott Elizabeth Closs, Dasher Richard B. 2002. Regularity in Semantic Change. Cambridge: Cambridge University Press.

Ultan Russel. 1978. "The Nature of Future Tenses.” In: GreENBERG 1978, vol. III: 83-123

VAN Der Auwera Johan. 2002. "More Thoughts on Degrammaticalization." In: Wischer \& Diewald 2002: 19-29.

Versteegh Kees, Eid Mushira, Elgibali Alaa, Woidich Manfred, Zaborski Andrzej (eds.). 2007. Encyclopedia of Arabic Language and Linguistics. Vol. 2. Leiden: Brill.

Wischer Illse, Diewald Gabriele (eds.). 2002. New Reflections on Grammaticalization. Proceedings from the International Symposium on Grammaticalization. (Typological Studies in Language, 49). Amsterdam-Philadelphia: John Benjamins.

\section{TRANSCRIPTION}

Description of place and manner of articulation of (unfamiliar) Syrian Arabic phonemes and their IPA transcriptions.

$\begin{array}{llll}\text { IPA } & \text { Description } & \text { IPA } & \text { Description } \\ \hbar & \text { Voiceless pharyngeal fricative } & \text { s } & \text { Voiceless dental fricative (emphatic) } \\ \mathrm{h} & \text { Glottal fricative } & \mathrm{\gamma} & \text { Voiced velar fricative } \\ \mathrm{P} & \text { Voiced glottal stop } & \mathrm{z} & \text { Voiced interdental fricative (emphatic) } \\ \mathrm{\varsigma} & \text { Voiced pharyngeal fricative } & \overline{\mathrm{a}} & \text { Low open long vowel } \\ \breve{\mathrm{s}} & \text { Voiceless alveolar fricative } & \overline{1} & \text { High front long vowel } \\ \mathrm{j} & \text { Voiced alveolar fricative } & \overline{\mathrm{u}} & \text { High back long vowel } \\ \mathrm{x} & \text { Voiceless uvular stop } & \overline{\mathrm{o}} & \text { Middle back long vowel } \\ \mathrm{t} & \text { Voiceless dental stop (emphatic) } & \overline{\mathrm{e}} & \text { Middle front vowel } \\ \mathrm{d} & \text { Voiced dental stop (emphatic) } & & \end{array}$

